\title{
PHYTOEXTRACTION OF CD, PB, ZN, CU AND MN BY INDIAN MUSTARD (BRASSICA JUNCEA L.) GROWN ON LOAMY SOIL AMENDED WITH HEAVY METAL CONTAMINATED MUNICIPAL SOLID WASTE COMPOST
}

\author{
SATPATHY, D. - REDDY, M.V.* \\ Department of Ecology and Environmental Sciences \\ Pondicherry University \\ Puducherry, Pondicherry 605 014, India \\ *Corresponding author \\ e-mail:Venkateshsrinivasl@gmail.com; prof.mvikramreddy@yahoo.com
}

(Received $16^{\text {th }}$ November 2011; accepted $2^{\text {nd }}$ September 2013)

\begin{abstract}
Accumulation of heavy metals - Cadmium (Cd), Lead (Pb), Zinc ( $\mathrm{Zn})$, Copper $(\mathrm{Cu})$ and Manganese (Mn) in root, stem and leaves of Indian mustard (Brassica juncea L.) grown on loamy coastal soil amended with different doses $\left(100,75,50,20\right.$, and 10 tha $\left.^{-1}\right)$ of municipal solid waste compost was assessed during a period of 45 days. Heavy metal accumulation in root, stem and leaves of the plants were significantly different across different amendments and sole soil $(\mathrm{P}<0.05)$. The ranking order of accumulated and translocated concentration of the heavy metals was $\mathrm{Pb}>\mathrm{Zn}>\mathrm{Cu}>\mathrm{Cd}>\mathrm{Mn}$ in the roots, which changed to $\mathrm{Mn}>\mathrm{Pb}>\mathrm{Zn}>\mathrm{Cd}>\mathrm{Cu}$ in the stem and to $\mathrm{Mn}>\mathrm{Pb}>\mathrm{Cd}>\mathrm{Zn}>\mathrm{Cu}$ in the leaves of the plants. The ranking order of heavy metal accumulation in different parts of the plant was root>stem>leaves for $\mathrm{Pb}, \mathrm{Zn}, \mathrm{Cu}$ and $\mathrm{Cd}$; however, it was stem>leaves>root for $\mathrm{Mn}$ across all the treatments. The accumulation of the metals increased gradually and significantly with the passage of time in days from 15 to 45 days $(\mathrm{p}<0.05)$.
\end{abstract}

Keywords: Bioaccumulation, Mobility Index, Phytoremediation, Translocation

\section{Introduction}

Municipal solid waste (MSW) including industrial waste when dumped in result Soil pollution causing heavy metal contamination of soil (Reddy and Pattnaik, 2009). The cause of the contamination is the presence of a broad range of inorganic and organic toxicants including the heavy metals, petroleum products and hazardous wastes (Ghosh and Singh, 2005). Heavy metals are the main component of the inorganic pollutants, and are at elevated concentrations (Reddy and Pattnaik, 2009). The heavy metals because of their persistence nature cause Soil and subsequently water pollution of the biosphere (Lasat, 2002). In the present century with advanced technologies and technical progress soil contamination by various pollutants has become one of the most significant environmental problems, which is likely to become more severe and widespread in the future. Sources of heavy metal contaminants in soils also include metal and ferrous mining and smelting, metallurgical industries, sewage sludge dumping, and contemporary agricultural practices - indiscriminate use of agricultural fertilizers (Alloway, 1995). Organic wastes including MSW compost are applied worldwide to improve soil physical properties and available soil nutrient levels and soil fertility ensuing in better plant growth mainly under low input agriculture (Gallardo-Lara and Nogales 1987; He et al., 1992; Ou eedraogo et al., 2001; Stamatiadis et al., 1999; De Jager et al., 2001). The main problems that can arise from excessive application of 
MSW compost are plant toxicity due to salt contents (Stamatiadis et al., 1999) and accumulation of trace metals in plants which may pose a health risk when humans or livestock consume the plants and their products (Petruzzelli, 1996; Cabrera et al., 1989).

Heavy metals, consequently, are of immense concern in the environment, because of its persistence and bioaccumulation and biomagnifications causing eco-toxicity to plants and animals including human beings (Kirkham, 2006). The removal of toxic heavy metals from waste is a major challenge for environmental managers and technologists. Some of the heavy metals e.g. $\mathrm{Zn}, \mathrm{Cu}, \mathrm{Mn}$ and $\mathrm{Ni}$ may be important essential micronutrients for plants, animals including human beings, while other highly toxic ones like $\mathrm{Hg}, \mathrm{Cd}, \mathrm{As}$ and $\mathrm{Pb}$ are hardly known to have any positive nutritional effects. Most of the heavy metals may cause toxic effects when occur in unwarranted concentrations, some of them even at a low concentration. Some of the heavy metals are not vital elements for plants, but can be readily taken up, translocated and accumulated in various plant parts. They pose a serious threat to human health reaching the body through food chains (Intawongse and Dean, 2006). Heavy metals when accumulate in high doses, also affect plants causing stunted growth and reducing their biomass production. Several effective ex-situ and in-situ remediation methods such as soil amendments, washing and replacement of polluted soils are applied for soil bioremediation, though most of them are too expensive and time consuming, and also require enormous amount of water and unpolluted soil (Abe et al., 2006). Now a day, phytoremediation has attracted great attention as a new and inexpensive environmental biotechnology (Salt et al., 1998) and it can be an ecosustainable mode of heavy metals removal using wetland plants (Rai, 2008). Phytoremediation involves the use of plants to remove, transfer, stabilize or degrade contaminants in soil, sediment and water (Hughes et al., 1997). Several comprehensive reviews have been written, summarizing different aspects of this novel plant- based technology (Raskin et al., 1997; Meagher, 2000; Garbisu and Alkorta, 2001; Prasad and Freitas, 2003; Alkorta et al., 2004; PilonSmits, 2005).

Phytoremediation technology involves removal of heavy metals from soil by accumulating in different plant parts. It is based on the capacity of the roots to absorb, concentrate and translocate the toxic metals from soil to the above ground plant parts. For instance, roots usually show higher heavy metal concentration than shoots, because they are the origin, and remain in contact with the toxic metals present in the soil (Breckle, 1991). In practice, metal-accumulating plants are seeded or transplanted to metal-contaminated soil and are cultured using conventional agricultural practices. The roots of cultivated plants absorb the metals from the soil and translocate them to the above-ground plant parts. After adequate plant growth and metal accumulation, the above- ground parts of the plant are harvested and taken out. This results in the permanent removal of metals from the site. The ideal plant for use in phytoextraction should have the following traits: (i) ability to accumulate the metal(s) intended to be extracted, preferably in the aboveground parts; (ii) tolerance to high metal concentrations in soils; (iii) fast growth and high accumulating biomass; (iv) easily grown as an agricultural crop and fully harvestable (Marchiol et al., 2004). Plants of the Brassicaceae are found to be promising for phytoremediation of metals, and different genera of the Brassicaceae are known to hyper-accumulate heavy metals such as $\mathrm{Pb}, \mathrm{Cd}$, Zn and Ni (Prasad and Freitas, 2003). At present, Indian mustard (B. juncea) is among the most viable candidates for the phytoextraction of a number of metals including $\mathrm{Cd}$, $\mathrm{Cr}, \mathrm{Cu}, \mathrm{Ni}, \mathrm{Pb}$, and $\mathrm{Zn}$ (Kumar et al., 1995; Blaylock et al., 1997). However, there are 
other factors that directly influence heavy metal concentration within plants, such as climate, nature of soil on which the crop is grown and the degree of maturity of the plant at harvesting (Scott et al., 1996; Voutsa et al., 1996). The nature of soil is considered as one of the important factors that determine heavy metal content of food plants (Itanna, 2002; Madyiwa et al., 2002a, b).

Though some investigations have been conducted on remediation of various heavy metals by different crop plants (Bunzl et al., 2001; Othman, 2001; Yusuf et al., 2002), little information is available on the bioaccumulation, mobility, and remediation of heavy metals by vegetable crop plants grown in soil amended with municipal solid waste compost particularly in tropical countries including India (Li et al., 2007; Gupta and Sinha, 2007; Gupta et al., 2008; Kumar et al., 2009). Xiong and Wang (2005) studied the copper toxicity and bioaccumulation in cabbage (Brassica pekinensis Rupr.) in China. Shyama et al. (2009) studied phytoextractive potential among mustard (Brassica juncea ) genotypes in Srilanka, Kumar et al. (2009) reported about hyper accumulation and mobility of heavy metals in vegetable crops in India. Gupta and Sinha (2007) showed the phytoextraction capacity of the Chenopodium album L. grown on soil amended with tannery sludge. The present study attempted to assess for the first time the bioaccumulation and determine the bio-transfer factor of $\mathrm{Cd}, \mathrm{Pb}, \mathrm{Zn}, \mathrm{Cu}$ and $\mathrm{Mn}$ in Indian mustard (B. juncea) grown on lateritic loamy soil amended with municipal solid waste compost.

\section{Materials and methods}

\section{Collection of samples}

The present experiment was carried out under the field conditions in Pondicherry university campus. The MSW compost for the experiment was collected from the main garbage dumping site - Karravadikuppam of Puducherry, a small town and the erstwhile French colony, about $160 \mathrm{~km}$ from Chennai on the east coast of India, and brought to the university campus for amendment of soil, lateritic loamy in nature.

\section{Field experiment design}

The field experiment was conducted with randomized block design of total 21 plots, seven treatments each with three replicates. Each experimental plot measured $30 \times 30$ $\mathrm{cm}^{2}$, which was amended with different doses of compost of MSW (100, 75, 50, 20 and $10 \mathrm{tha}^{-1}$ ), control (the sole native soil) and three pits each of $30 \times 30 \times 30 \mathrm{~cm}^{2}$ filled with the sole MSW compost. The MSW compost was broad casted on the surface and mixed thoroughly with the soil by hand digging 5 days prior to seed sowing. After the MSW compost application, seeds of $B$. juncea were sown on the surface of each treatment and also in control (without application of any MSW compost) at the density of 100 plants per plot per treatment. During the period of the experiment Plants were regularly watered with tap fitted with a shower. Plants were carefully harvested along with the root at 15days, 30days and 45days of the experiment, and root, stem and leaves were separated with the help of a sharp scalpel to carry out the heavy metal analysis of the plant parts i.e., roots, stem and leaves. 


\section{Plant analysis}

Analyses of metals of roots, stem and leaves of the plants were carried out by the method described by Li et al. (2007). Root, stem and leaves were washed thoroughly with deionized water to remove adhered soil particles, and then air-dried for 48 hours, followed by oven-drying at $70{ }^{\circ} \mathrm{C}$ for 48 hours and their dry weights were recorded. Dried plant tissue was ground to fine powder and burnt to ash at $650{ }^{\circ} \mathrm{C}$ in muffle's furnace. It was digested with a mixture of $\mathrm{HNO}_{3}+\mathrm{HClO}_{4}$ following the method of Shahmansouri et al. (2005) and Epelde et al. (2008). The total heavy metal concentrations $(\mathrm{Cd}, \mathrm{Cu}, \mathrm{Pb}, \mathrm{Mn}$ and $\mathrm{Zn})$ of all the plant samples were then determined by using Atomic Absorption Spectrophotometer (AAS) of GBC make - Model Avanta PM.

\section{Biological Accumulation Coefficient (BAC) and Biological Transfer Coefficient (BTC)}

The Biological Accumulation Coefficient (BAC) of a plant in relation to certain heavy metals is the metal concentration of its aboveground part (mainly leaf or leaf plus stem) divided by the same metal content in soil (Kumar et al., 2009). Biological Transfer Coefficient (BTC) is the heavy metal concentration of aboveground plant tissues divided by the concentration of same metal in roots (Li and Xiong, 2004; Li et al., 2007; Mishra et al., 2008), while Mobility Index (MI) for each level was calculated to determine relative translocation of metals at Level1(soil to root), Level 2 (root to stem) and Level 3(stem to leaves) of the plant species by using the formula concentration of metal in receiving level divided by concentration of the same metal in the source level (Barman et al., 2000; Gupta et al., 2008; Kumar et al., 2009).

\section{Statistical Analysis}

Statistical evaluation was applied to the data collected from the study, and the values were presented as the mean \pm SD (standard deviation). Two way ANOVA was used to determine the significant difference between heavy metal contents of different plant parts (root, stem and leaves).

\section{Results}

Accumulation of Heavy Metals in the plants grown in soil amended with MSW compost in relation to that grown in native soil

The concentrations of the heavy metals $\mathrm{Pb}, \mathrm{Mn}, \mathrm{Zn}, \mathrm{Cd}$ and $\mathrm{Cu}$ in root, stem and leaves of $B$. juncea across different treatments were compared with that of the control. The concentrations of the metals were higher in all plant parts under the influence of treatments compared to that of the control (Fig. 1, 2, 3, 4 and 5). The ranking order of accumulation of the heavy metals were $\mathrm{Pb}>\mathrm{Zn}>\mathrm{Mn}>\mathrm{Cu}>\mathrm{Cd}$ for roots and $\mathrm{Mn}>\mathrm{Pb}$ $>\mathrm{Zn}>\mathrm{Cu}>\mathrm{Cd}$ for stem and leaves. The concentrations of $\mathrm{Pb}, \mathrm{Zn}, \mathrm{Mn}, \mathrm{Cd}$ and $\mathrm{Cu}$ in different plant parts increased from 15 to 30 days and were highest at 45 days. The order of accumulation of the heavy metals in different parts of $B$. juncea was root > stem $>1$ eaf for $\mathrm{Pb}, \mathrm{Zn}, \mathrm{Cu}$ and $\mathrm{Cd}$; and it was stem>leaf $>$ root for $\mathrm{Mn}$ across all the treatments. 


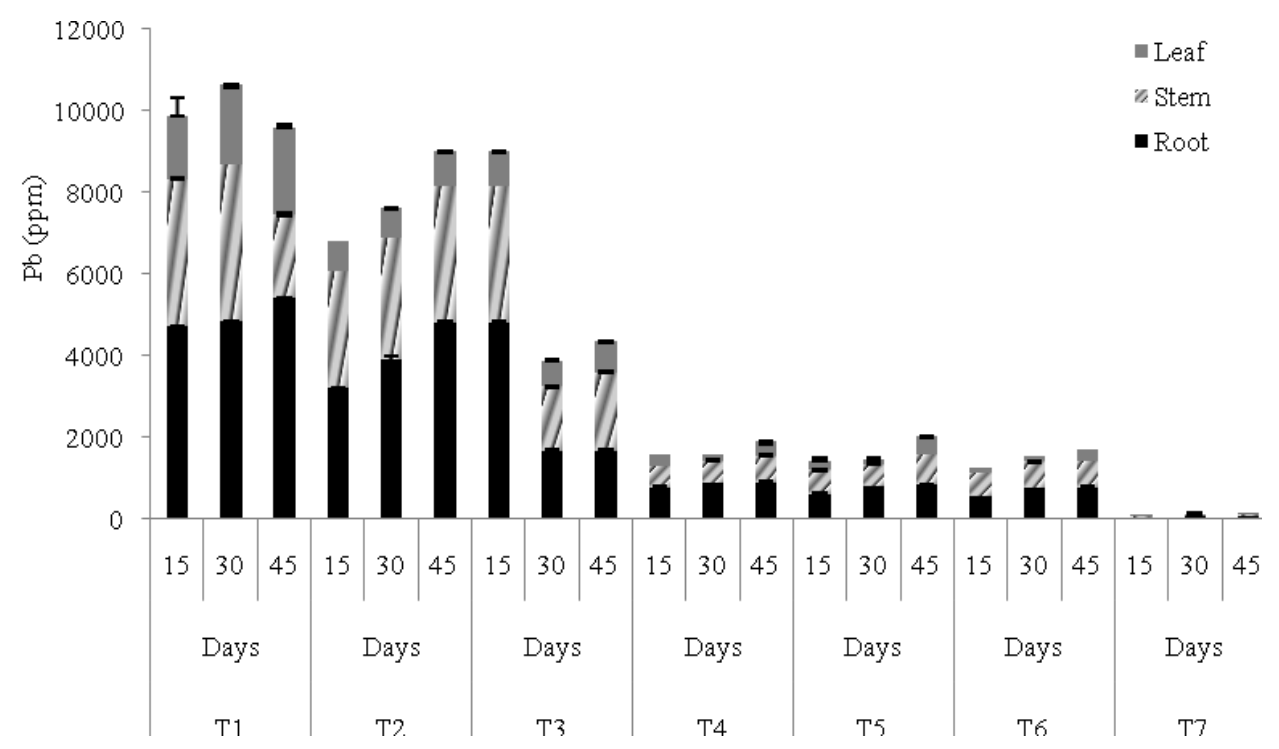

Figure 1. Concentration (ppm) of Pb in different plant parts (Root, Stem and Leaves) at 15 days, 30 days and 45 days across the treatments

Accumulation of $\mathrm{Pb}$ was significantly higher in root than that of stem and leaves $(\mathrm{p}<$ 0.05 ) across all the amendments (Table 2) (Figure 1), and on the contrast, it was significantly lesser in plants grown in control than that in treatments $(\mathrm{p}<0.05)$ (Table 2).

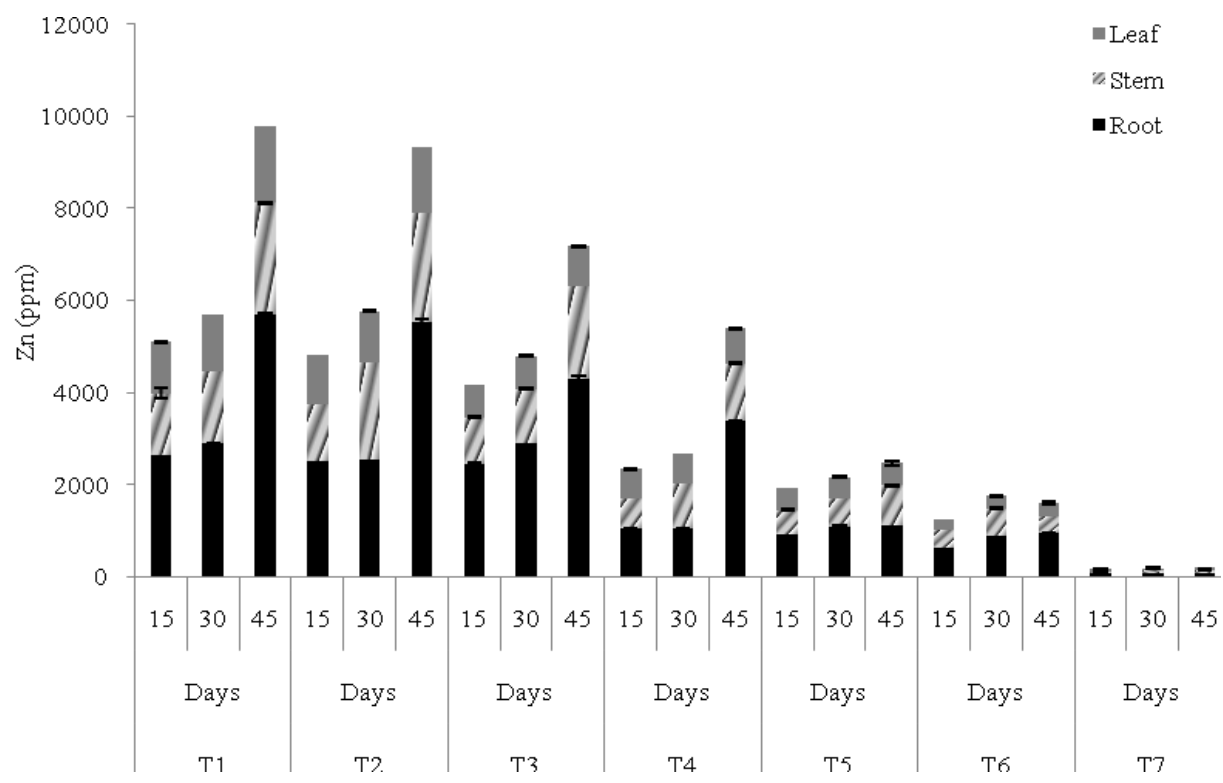

Figure 2. Concentration (ppm) of Zn in different plant parts (Root, Stem and Leaves) at 15 days, 30 days and 45 days across the treatments 


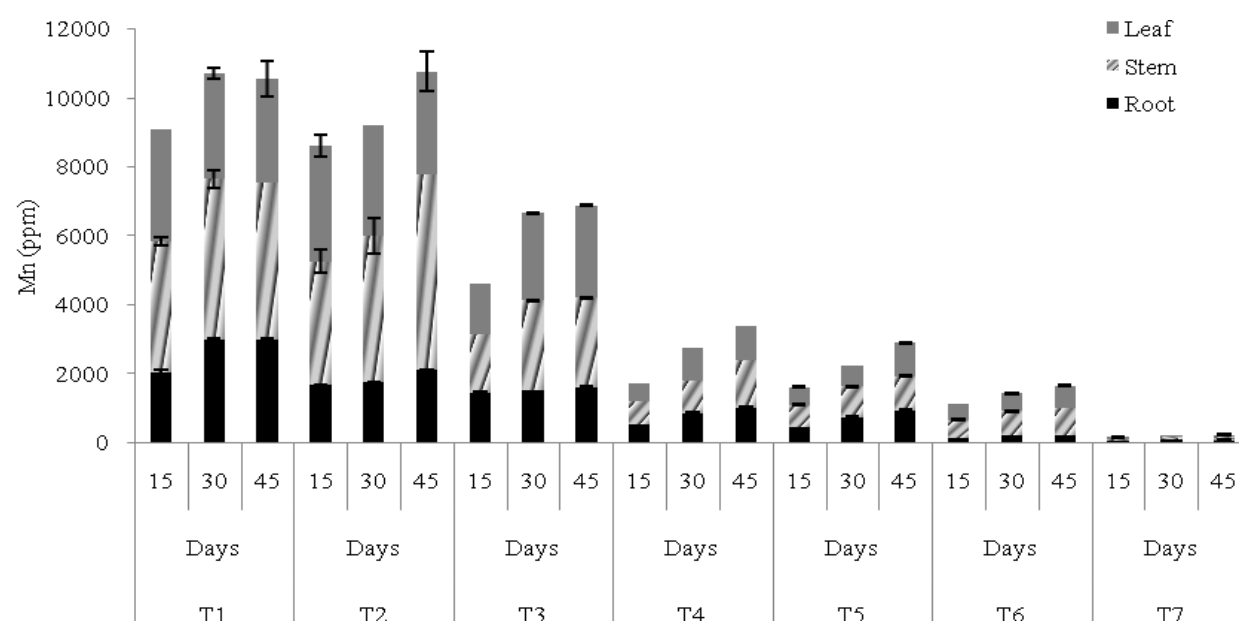

Figure 3. Concentration (ppm) of Mn in different plant parts (Root, Stem and Leaves) at 15 days 30 days and 45 days across the treatments

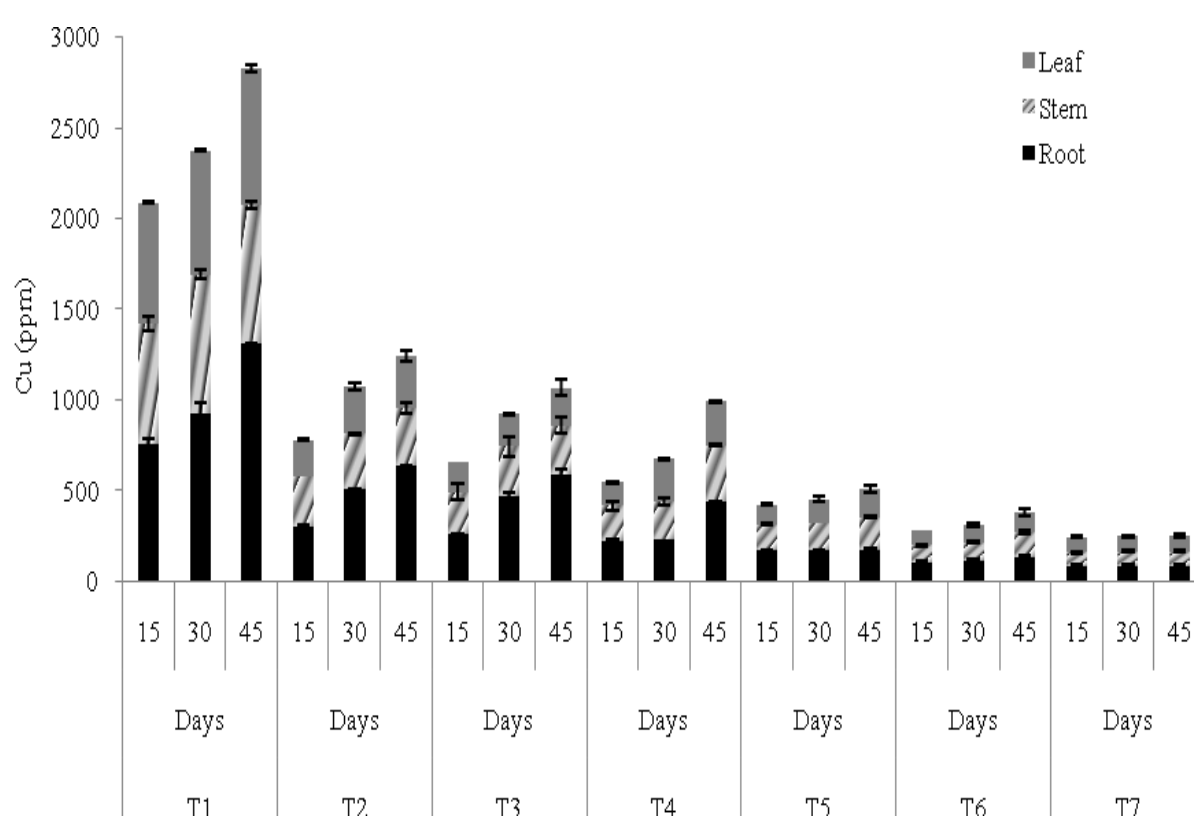

Figure 4. Concentration (ppm) of $\mathrm{Cu}$ in different plant parts (Root, Stem and Leaves) at 15 days, 30 days and 45 days across the treatments

The accumulation concentration increased significantly from 15 days to 45 days ( $\mathrm{p}<$ 0.05). The ranges of $\mathrm{Pb}$ accumulation were 36.9 to $4703.4 \mathrm{ppm}, 34.0$ to $3627.3 \mathrm{ppm}$ and 33.4 to $1541.9 \mathrm{ppm}$ in root, stem and leaves, respectively at 15 days across the treatments as well as soil. Similarly, the ranges were 52.22 to $4828.7 \mathrm{ppm}, 37.4$ to $3850.2 \mathrm{ppm}$ and 34.2 to $1968.4 \mathrm{ppm}$ in root, stem and leaves, respectively at 30 days while it ranged from 64.7 to $5405.3 \mathrm{ppm}, 47.1$ to $2036.1 \mathrm{ppm}$ and 39.9 to $2123.6 \mathrm{ppm}$ in 
root, stem and leaves, respectively at 45 days across the treatments and soil. Similarly, $\mathrm{Zn}$ accumulation was significantly higher in root than that of stem and leaves $(\mathrm{p}<0.05)$ (Table 2) (Figure 2). However, its accumulation was significantly less in plant grown in control than that in treatments $(\mathrm{p}<0.05)$ (Table 2). The accumulation of $\mathrm{Zn}$ increased significantly from 15 days to 45 days $(\mathrm{p}<0.05)$. The ranges of $\mathrm{Zn}$ accumulation were 60.9 to $2638.0 \mathrm{ppm}, 49.9$ to $1341.6 \mathrm{ppm}$ and 46.2 to $1108.1 \mathrm{ppm}$ in root, stem and leaves, respectively at 15 days across the treatments and soil, while the ranges were 67.8 to 2888.5ppm, 63.0 to $1572.3 \mathrm{ppm}$ and 53.7 to $1221.4 \mathrm{ppm}$ in root, stem and leaves, respectively at 30 days whereas it ranged from 71.9 to $5677.7 \mathrm{ppm}, 71.5$ to $2434.0 \mathrm{ppm}$ and 57.8 to $1666.8 \mathrm{ppm}$ in root, stem and leaves, respectively at 45 days across the treatments and soil. The accumulation of Mn was also significantly higher in stem than that of leaves and root $(\mathrm{p}<0.05)$ (Table 2) (Figure 3). Its accumulation was significantly lesser in plants grown in control than that in the treatments $(p<0.05)$ (Table 2). The accumulation of $\mathrm{Mn}$ increased significantly from 15 days to 45 days ( $\mathrm{p}<$ $0.05)$. Its concentration was more in stem than that in leaves and root. The ranges of $\mathrm{Mn}$ accumulation were 46.0 to $2041.5 \mathrm{ppm}, 57.0$ to $3781.0 \mathrm{ppm}$ and 50.1 to $3260.8 \mathrm{ppm}$ in root, stem and leaves, respectively at 15 days across the treatments and soil. The range were 80.8 to $2962.9 \mathrm{ppm}, 81.4$ to $4675.3 \mathrm{ppm}$ and 61.0 to $3049.5 \mathrm{ppm}$ in root, stem and leaves, respectively at 30 days, whereas it ranged from 68.9 to $2974.6 \mathrm{ppm}, 89.8$ to $4552.3 \mathrm{ppm}$ and 66.4 to $3003.4 \mathrm{ppm}$ in root, stem and leaves, respectively at 45 days across the treatments and soil.

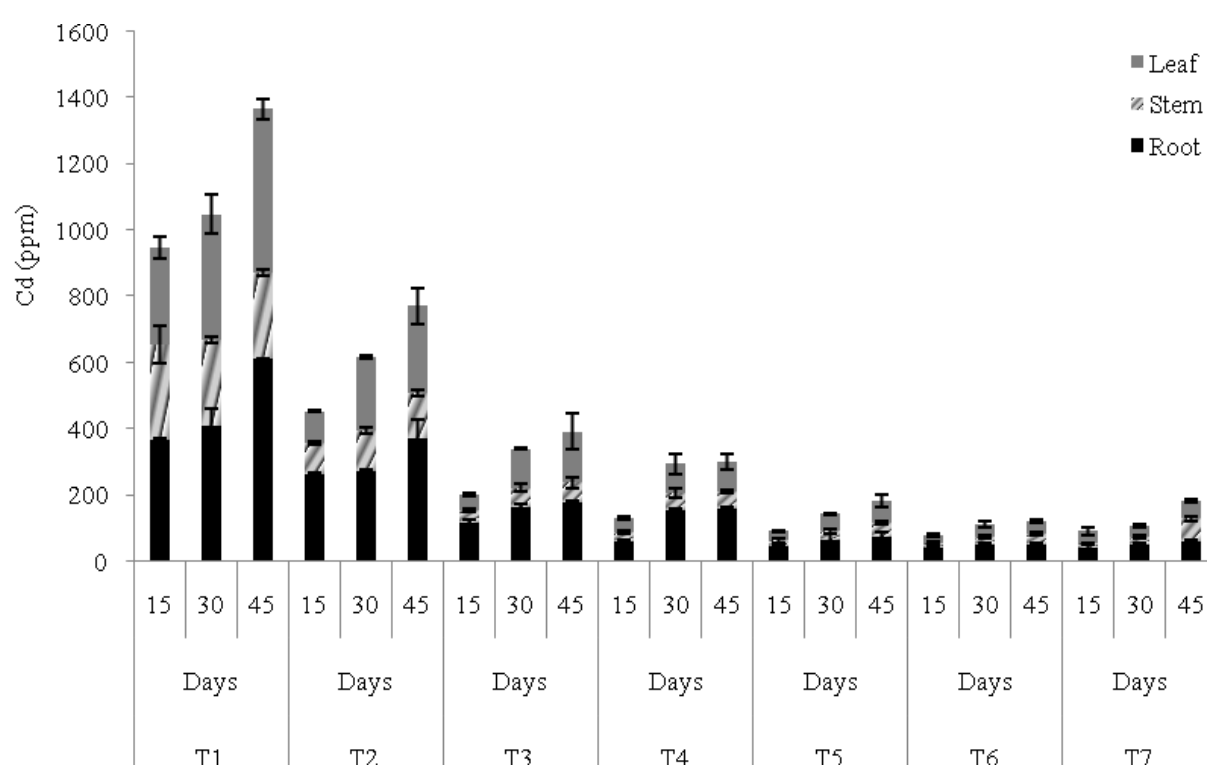

Figure 5. Concentration (ppm) of Cd in different plant parts (Root, Stem and Leaves) at 15 days, 30 days and 45 days across the treatments

$\mathrm{Cu}$ accumulation was as well significantly higher in root than that of stem and leaves ( $<<0.05)$ (Table 2) (Figure 4); while its accumulation was significantly lesser in plant grown in control than that treatments $(\mathrm{p}<0.05)$ (Table 2). The accumulation increased significantly from 15 days to 45 days $(\mathrm{p}<0.05)$. The ranges of $\mathrm{Cu}$ accumulation were 
80.0 to $751.7 \mathrm{ppm}, 79.0$ to $669.1 \mathrm{ppm}$ and 82.5 to $666.7 \mathrm{ppm}$ in root, stem and leaves, respectively at 15 days across the treatments and soil. The range were 82.8 to 926.6 ppm, 81.8 to $763.1 \mathrm{ppm}$ and 80.2 to $683.6 \mathrm{ppm}$ in root, stem and leaves, respectively at 30 days whereas it ranged from 78.1 to $1306.8 \mathrm{ppm}, 84.7$ to $764.3 \mathrm{ppm}$ and 82.9 to $754.8 \mathrm{ppm}$ in root, stem and leaves, respectively at 45 days across the treatments and soil. Cd accumulation too was significantly higher in root than that of stem and leaves $(\mathrm{p}<0.05)$ (Table 2) (Figure 5). Its accumulation was significantly lesser in plants grown in control than that in other treatments $(\mathrm{p}<0.05)($ Table 2). The accumulation of $\mathrm{Cd}$ increased significantly from 15 days to 45 days $(\mathrm{p}<0.05)$.Its concentration was more in root than that in stem and leaves. The ranges of $\mathrm{Cd}$ accumulation were 41.5 to $367.2 \mathrm{ppm}, 13.4$ to $287.8 \mathrm{ppm}$ and 37.1 to $292.7 \mathrm{ppm}$ in root, stem and leaves, respectively at 15 days across the treatments and soil; and were 50.9 to $410.2 \mathrm{ppm}, 24.4$ to $258.8 \mathrm{ppm}$ and 32.9 to $379.5 \mathrm{ppm}$ in root, stem and leave respectively at 30 days whereas it ranged from 60.9 to $610.6 \mathrm{ppm}, 68.0$ to $258.9 \mathrm{ppm}$ and 55.4 to $495.4 \mathrm{ppm}$ in root, stem and leaves respectively at 45 days across the treatments and soil.

Table 1. Types of treatments

\begin{tabular}{c|c}
\hline Treatments & Description \\
\hline T1 & $100 \% \mathrm{MSW}$ \\
T2 & $100 \mathrm{t}$ of MSW /ha \\
T3 & $75 \mathrm{t} \mathrm{of} \mathrm{MSW} \mathrm{/ha}$ \\
T4 & $50 \mathrm{t} \mathrm{of} \mathrm{MSW} \mathrm{/ha}$ \\
T5 & $20 \mathrm{t} \mathrm{of} \mathrm{MSW} \mathrm{/ha}$ \\
T6 & $10 \mathrm{t} \mathrm{of} \mathrm{MSW} \mathrm{/ha}$ \\
T7 & $0 \mathrm{t} \mathrm{of} \mathrm{MSW} \mathrm{/ha} \mathrm{(Soil)}$ \\
\hline
\end{tabular}

\section{Percentage translocation of heavy metals from soil substrate by the plant parts}

Removal of $\mathrm{Pb}$ by root, and translocated to stem and leaves was 0.04 to $0.05 \%, 0.01$ to $0.05 \%$ and 0.01 to $0.02 \%$ respectively across different treatments and control, while removal of $\mathrm{Zn}$ by root, and translocated to stem and leaves was 0.04 to $0.1 \%, 0.02$ to $0.03 \%$ and 0.01 to $0.03 \%$ respectively across different treatments and the control. Removal of Mn by root and translocated to stem and leaves was 0.03 to $0.07 \%, 0.05$ to $0.2 \%$ and 0.04 to $0.1 \%$ respectively across different treatments and native soil; while removal of $\mathrm{Cu}$ by root, and translocated to stem and leaves was 0.03 to $0.07 \%, 0.03$ to $0.04 \%$ and 0.02 to $0.03 \%$ respectively across different treatments and native soil. Removal of $\mathrm{Cd}$ by root, and translocated to stem and leaves was respectively, 0.04 to $0.07 \%, 0.02$ to $0.05 \%$ and 0.03 to $0.04 \%$ across different treatments and native soil. 
Table 2. Analysis of variance (ANOVA) of concentrations of $\mathrm{Pb}, \mathrm{Zn}$ and $\mathrm{Mn}$ in different parts of plants grown across different treatments

\begin{tabular}{|c|c|c|c|c|}
\hline $\begin{array}{l}\text { Source of } \\
\text { Variation }\end{array}$ & $S S$ & $d f$ & $M S$ & $F$ \\
\hline \multicolumn{5}{|l|}{$\begin{array}{c}P b \\
(15 \text { days })\end{array}$} \\
\hline Across treatments & 25514581 & 6 & 4252430 & $10.54015 * *$ \\
\hline Across plant parts & 4510207 & 2 & 2255103 & $5.589542 * *$ \\
\hline Error & 4841405 & 12 & 403450.4 & \\
\hline Total & 34866193 & 20 & & \\
\hline \multicolumn{5}{|l|}{ (30 days) } \\
\hline Across treatments & 30087721 & 6 & 5014620 & $12.79857 * *$ \\
\hline Across plant parts & 6182085 & 2 & 3091042 & $7.889117 * *$ \\
\hline Error & 4701732 & 12 & 391811 & \\
\hline Total & 40971537 & 20 & & \\
\hline \multicolumn{5}{|l|}{ (45 days) } \\
\hline Across treatments & 28119111 & 6 & 4686519 & $5.64561 * *$ \\
\hline Across plant parts & 6580475 & 2 & 3290238 & $3.963582 *$ \\
\hline Error & 9961408 & 12 & 830117.3 & \\
\hline Total & 44660994 & 20 & & \\
\hline \multicolumn{5}{|l|}{$\begin{array}{c}\text { Zn } \\
\text { (15 days) }\end{array}$} \\
\hline Across treatments & 7186309 & 6 & 1197718 & $8.441567 * *$ \\
\hline Across plant parts & 2972066 & 2 & 1486033 & $10.47362 * *$ \\
\hline Error & 1702601 & 12 & 141883.4 & \\
\hline Total & 11860976 & 20 & & \\
\hline \multicolumn{5}{|l|}{ (30 days) } \\
\hline Across treatments & 9249815 & 6 & 1541636 & $8.08869 * *$ \\
\hline Across plant parts & 3506063 & 2 & 1753032 & $9.197846 * *$ \\
\hline Error & 2287098 & 12 & 190591.5 & \\
\hline Total & 15042977 & 20 & & \\
\hline \multicolumn{5}{|l|}{ (45 days) } \\
\hline Across treatments & 29085804 & 6 & 4847634 & $5.676915^{* *}$ \\
\hline Across plant parts & 18449056 & 2 & 9224528 & $10.80256^{* *}$ \\
\hline Error & 10247046 & 12 & 853920.5 & \\
\hline Total & 57781906 & 20 & & \\
\hline \multicolumn{5}{|l|}{$\begin{array}{c}\text { Mn } \\
\text { (15 days) }\end{array}$} \\
\hline Across treatments & 27030781 & 6 & 4505130 & $23.25432 * *$ \\
\hline Across plant parts & 1620388 & 2 & 810194 & $4.182013^{*}$ \\
\hline Error & 2324796 & 12 & 193733 & \\
\hline Total & 30975965 & 20 & & \\
\hline \multicolumn{5}{|l|}{ (30 days) } \\
\hline Across treatments & 33510183 & 6 & 5585030 & $19.88166 * *$ \\
\hline Across plant parts & 2515287 & 2 & 1257644 & $4.476976^{*}$ \\
\hline Error & 3370964 & 12 & 280913.6 & \\
\hline Total & 39396434 & 20 & & \\
\hline \multicolumn{5}{|l|}{ (45 days) } \\
\hline Across treatments & 35982895 & 6 & 5997149 & $12.48642 * *$ \\
\hline Across plant parts & 3725823 & 2 & 1862912 & $3.878692 *$ \\
\hline Error & 5763525 & 12 & 480293.7 & \\
\hline Total & 45472242 & 20 & & \\
\hline
\end{tabular}


Table 3. Analysis of variance (ANOVA) of concentrations of $\mathrm{Cu}$ and $\mathrm{Cd}$ in different parts of plants grown across different treatments

\begin{tabular}{|c|c|c|c|c|}
\hline Source of Variation & $S S$ & $d f$ & $M S$ & $F$ \\
\hline \multicolumn{5}{|l|}{ (15 days) } \\
\hline Across treatments & 806970.9 & 6 & 134495.2 & $231.0974 * *$ \\
\hline Across plant parts & 13419.65 & 2 & 6709.826 & $11.52922 * *$ \\
\hline Error & 6983.816 & 12 & 581.9846 & \\
\hline Total & 827374.4 & 20 & & \\
\hline \multicolumn{5}{|l|}{ (30 days) } \\
\hline Across treatments & 1075092 & 6 & 179182 & $37.66138^{* *}$ \\
\hline Across plant parts & 52783.7 & 2 & 26391.85 & $5.547172 * *$ \\
\hline Error & 57092.55 & 12 & 4757.713 & \\
\hline Total & 1184968 & 20 & & \\
\hline \multicolumn{5}{|l|}{ (45 days) } \\
\hline Across treatments & 1528695 & 6 & 254782.6 & $16.31979 * *$ \\
\hline Across plant parts & 186985.8 & 2 & 93492.91 & $5.988575^{* *}$ \\
\hline Error & 187342.5 & 12 & 15611.88 & \\
\hline Total & 1903024 & 20 & & \\
\hline \multicolumn{5}{|l|}{$\begin{array}{c}\text { Cd } \\
\text { (15 days) }\end{array}$} \\
\hline Across treatments & 205017.4 & 6 & 34169.56 & $32.63258 * *$ \\
\hline Across plant parts & 16816.44 & 2 & 8408.219 & $8.030009 * *$ \\
\hline Error & 12565.19 & 12 & 1047.099 & \\
\hline Total & 234399 & 20 & & \\
\hline \multicolumn{5}{|l|}{ (30 days) } \\
\hline Across treatments & 237949.3 & 6 & 39658.22 & $45.03361 * *$ \\
\hline Across plant parts & 26623.45 & 2 & 13311.72 & $15.11603 * *$ \\
\hline Error & 10567.63 & 12 & 880.636 & \\
\hline Total & 275140.4 & 20 & & \\
\hline (45 days) & & & & \\
\hline Across treatments & 403935.3 & 6 & 67322.54 & $15.01891 * *$ \\
\hline Across plant parts & 54168.63 & 2 & 27084.32 & $6.04221 * *$ \\
\hline Error & 53790.22 & 12 & 4482.518 & \\
\hline Total & 511894.1 & 20 & & \\
\hline
\end{tabular}

Level of significance $* * \mathrm{P}<0.01 ; * \mathrm{P}<0.05$

\section{The Bio-Accumulation Coefficient (BAC) and Bio-Transfer Coefficient (BTC)}

The BACs explain the accumulation of the heavy metals in different parts of the plant across the treatments with respect to soil as the substrate. The range of BACs of $\mathrm{Pb}$ for the plant was 1.9 to $2.2,2.0$ to 2.7 and 2.3 to 3.1 at 15,30 and 45 days, respectively across different treatments and the soil. The range of BACs of $\mathrm{Zn}$ for the plant was 1.6 to $2.3,1.8$ to 2.7 and 2.5 to 4.8 at 15,30 and 45 days, respectively across different treatments and the control. The range of Mn was 2.7 to 4.9, 4.1 to 5.0 and 5.0 to 11.2 at 15, 30 and 45 days, respectively across different treatments and the soil. The range of BACs of $\mathrm{Cu}$ was 2.3 to 2.7, 2.6 to 3.5 and 2.8 to 4.2 at 15,30 and 45 days, respectively across different treatments and the soil whereas for $\mathrm{Cd}$ the range was 1.7 to $2.5,2.3$ to 4.3 and 2.9 to 4.4 at 15,30 and 45 days, respectively across different treatments and the soil. The range of BACs showed that higher concentration of $\mathrm{Pb}, \mathrm{Zn}$, 
$\mathrm{Cd}$ and $\mathrm{Cu}$ were accumulated in root than stem and leaves, while accumulating concentration of $\mathrm{Mn}$ was higher in stem and leaves than that of root.

The BTCs indicate the mobility of the heavy metals across different plant parts across the treatments. It is the transfer of heavy metals from root to aerial parts (stem + leaves). The range of BTC of $\mathrm{Pb}$ was 1.0 to $1.8,0.8$ to 1.4 and 0.8 to 1.6 at 15,30 and 45 days, respectively across different treatments and the control. The range of $\mathrm{Zn}$ was 0.7 to $1.6,0.6$ to 1.7 and 0.6 to 1.8 at 15,30 and 45 days, respectively across the treatments and control. The range for Mn was 2.2 to $6.9,1.8$ to 5.5 and 2.1 to 6.4 at 15 , 30 and 45 days, respectively across different treatments and the soil. The range for $\mathrm{Cu}$ was 1.5 to $2.0,1.0$ to 2.0 and 0.8 to 2.1 at 15,30 and 45 days, respectively across the treatments and the control whereas for $\mathrm{Cd}$, the range was 1.0 to $1.6,0.9$ to 1.6 and 0.9 to 2.0 at 15, 30 and 45 days respectively across the treatments and soil. The range for Accumulation of the heavy metals $(\mathrm{Pb}, \mathrm{Zn}, \mathrm{Mn}, \mathrm{Cu}$, and $\mathrm{Cd})$ in $B$. juncea is positively and significantly $(\mathrm{p}<0.001)$ correlated with the concentration of the heavy metals present in different treatments (Table 2).

\section{Mobility of Heavy Metals across the plant parts}

Mobility Index (MI) showed mobility and transport of heavy metals through different levels: Level 1, Level 2 and Level 3 in the plants, which becomes functional to understand the translocation mechanism of heavy metals across the plant parts, such as root, stem and leaves.

In Level 1, the range of $\mathrm{MI}$ for $\mathrm{Pb}$ was 1.0 to $1.5,0.8$ to 1.0 and 0.7 to 0.9 at 15 days, 30 days and 45 days, respectively across the treatments and native soil. In Level 2, the range of mobility factor was 0.7 to $1.0,0.7$ to 0.9 and 0.4 to 1.2 at 15 days, 30 days and 45 days, respectively. In Level 3, the range of mobility factor was 0.2 to $1.0,0.2$ to 0.9 and 0.3 to 1.0 at 15 days, 30 days and 45 days, respectively across the treatments and soil.

The MI for $\mathrm{Zn}$ in Level 1 ranged from 0.8 to $1.0,0.9$ to 1.4 and 1.1 to 2.1 at 15 days, 30 days and 45 days, respectively across the treatments and native soil; in Level 2, the range was 0.4 to $0.8,0.4$ to 0.9 and 0.4 to 1.0 at 15,30 and 45 days respectively, across the treatments and native soil, and in Level 3, the range was 0.6 to $1.0,0.5$ to 0.9 and 0.4 to 0.8 at 15, 30 and 45 days respectively, across the treatments and soil.

The MI for Mn in Level 1 ranged from 0.8 to 1.0, 0.9 to 1.7 and 1.0 to 1.6 at 15 days, 30 days and 45 days, respectively across the treatments and soil; in Level 2, the range was 1.2 to $3.7,1.0$ to 3.1 and 1.3 to 3.5 at 15 days, 30 days and 45 days, respectively across the treatments and soil, and in Level 3, range was 0.8 to $0.9,0.7$ to 1.0 and 0.5 to 1.0 at 15, 30 and 45 days across the treatments and soil.

In Level 1, the MI for $\mathrm{Cu}$ ranged from 0.9 to $1.0,0.9$ to 1.8 and 0.9 to 2.2 at 15 days, 30 days and 45 days respectively across the treatments and soil. In Level 2, the range was 0.9 to $1.0,0.8$ to 1.0 and 0.5 to 1.1 at 15,30 and 45 days respectively and across the treatments and soil. In Level 3 the range was 0.7 to $1.0,0.6$ to 1.2 and 0.8 to 1.0 at 15 days, 30 days and 45 days respectively across the treatments and soil.

In Level 1, for Cd however, the MI ranged from 0.9 to $1.0,1.1$ to 2.2 and 1.2 to 2.3 at 15 days, 30 days and 45 days respectively across the treatments and soil. In Level 2, the range was 0.3 to $0.8,0.3$ to 0.6 and 0.3 to 1.1 at 15 days, 30 days and 45 days respectively across the treatments and soil. In Level 3 the range was 1.0 to $2.8,1.3$ to 2.1 and 0.8 to 2.7 at 15 days, 30 days and 45 days, respectively across the treatments and soil. 
Table 4. Mobility Index of the heavy metals across the treatments at 15,30 and 45 days respectively in level-1.2 and 3

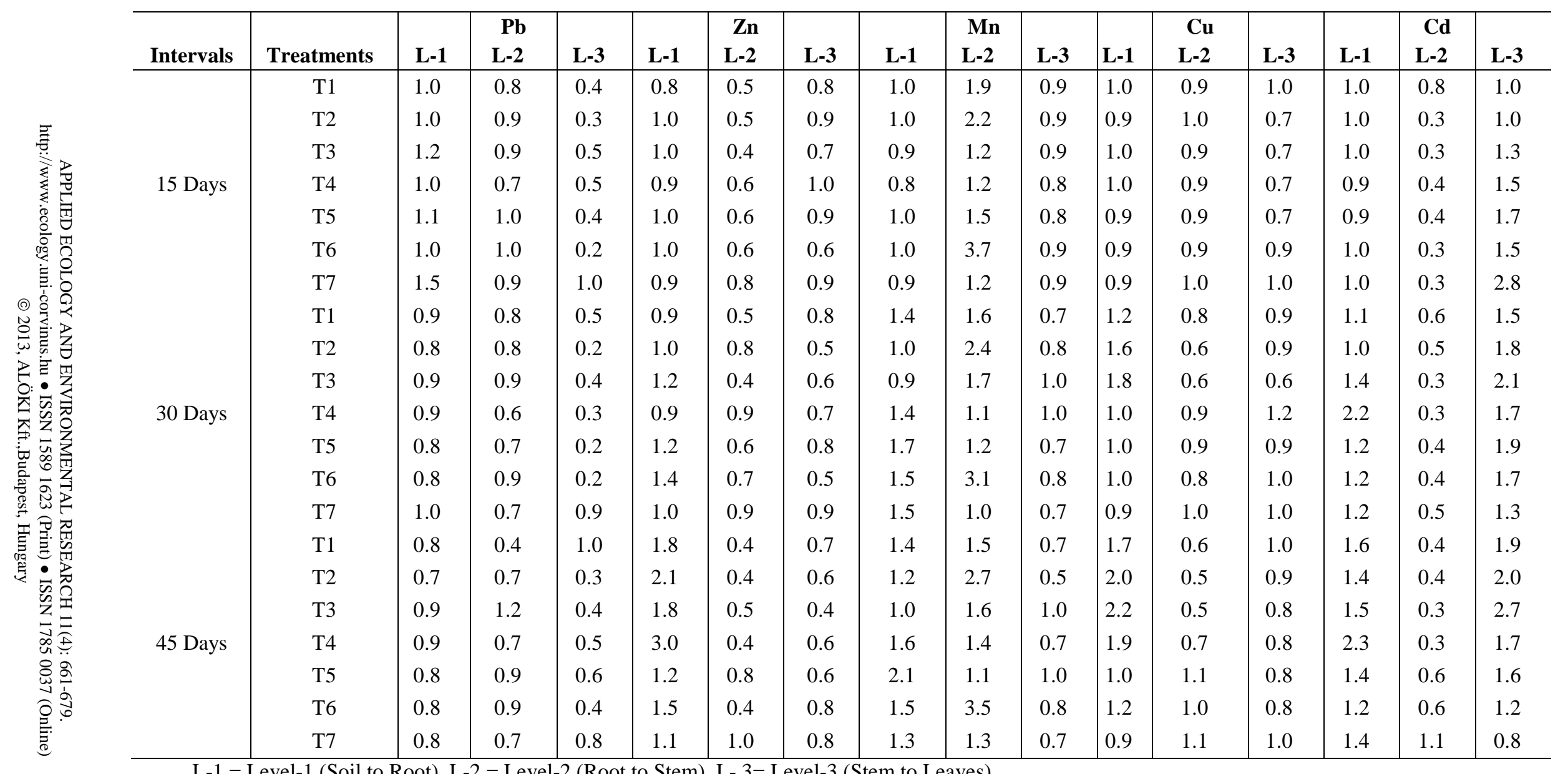




\section{Discussion}

The present study showed that B. Juncea absorbed the heavy metals $-\mathrm{Cr}, \mathrm{Cu}, \mathrm{Mn}$, $\mathrm{Zn}$ and $\mathrm{Cd}$ and translocated them to the aerial parts, stem and leaves. In consistence to the present findings Gupta et al. (2008) assessing the heavy metal accumulation in three species of macrophytes, showed the translocation of $\mathrm{Fe}, \mathrm{Cr}, \mathrm{Cu}, \mathrm{Mn}, \mathrm{Zn}$ and $\mathrm{Cd}$ from soil to shoot through root. Plants absorb and translocate both the essential and nonessential elements from soils and soils amended with municipal organic solid waste compost. The accumulation of heavy metals in different plant parts is known to depend upon the amount of metals present in the soil and its amendments, and the level of heavy metal accumulation differs within and between species of plants (Huang and Cunningham, 1996; McGrath et al., 2002). (Bernal et al., 2005) in their study found that although organic amendments play an important role in the availability of these elements, their effects will change with time and soil $\mathrm{pH}$ conditions. (Marchiol et al., 2004) measured the concentration of heavy metals in the tissues of canola and radish plants grown on polluted soil substrate was higher than in the control which was also found in the present study.

The accumulation of $\mathrm{Pb}, \mathrm{Zn}, \mathrm{Cu}$ and $\mathrm{Cd}$ in $B$.juncea in the present study was more in root followed by stem and leaves, whereas accumulation of $\mathrm{Mn}$ was more in stem followed by leaves and minimum in roots root. The higher accumulating concentration of heavy metals in different plant parts in $B$.juncea indicated that it is a hyperaccumulator. The present concentrations of $\mathrm{Pb}, \mathrm{Cd}, \mathrm{Zn}, \mathrm{Cu}$ and $\mathrm{Mn}$ are higher compared to the recommended tolerable levels proposed by joint FAO/WHO Expert Committee on Food Additives for leaves, stem and root of different vegetables, which are $0.3,5.0,60.0$, and $40.0 \mathrm{mg} \mathrm{kg}^{-1}$ in $\mathrm{Cd}, \mathrm{Pb}, \mathrm{Zn}$, and $\mathrm{Cu}$, respectively (Codex Alimentarius Commission, 1984; Farooq et al., 2008), while the permissible limit for $\mathrm{Cu}$ and $\mathrm{Zn}$ are $<200$ and $<500 \mathrm{mg} \mathrm{kg}^{-1}$ dry wt of leaves (Food Standards Committee, 1950) (guidelines, $\mathrm{UK}$ ), and for $\mathrm{Cd}$ and $\mathrm{Pb}$ are $<2$ and $<3 \mathrm{mg} \mathrm{kg}^{-1}$ dry wt of leaves (FAO/WHO, Codex Alimentarius, 2001a, b) which are lower compared to the levels recorded in the present study.

Pichtel and Salt (1998) found, in a greenhouse study, shoot tissue of Phleum pratense, Agrostis capillaris and Lolium perenne accumulating 141, 122 and $120 \mathrm{mg}$ $\mathrm{kg}^{-1}$ of $\mathrm{Pb}$, respectively. Pichtel and Salt, (1998) measured $\mathrm{Pb}$ values for root, which were 9610 and $9740 \mathrm{mg} \mathrm{kg}^{-1}$, indicating high mobility of $\mathrm{Pb}$ from the soil to root. In the present study the $\mathrm{Pb}$ concentration in root is $5405.3 \mathrm{mg} \mathrm{kg}^{-1}$, stem $2036.1 \mathrm{mg} \mathrm{kg}^{-1}$ and leaves $2123.6 \mathrm{mg} \mathrm{kg}^{-1}$ which is higher than the permissible limits (FAO/WHO, Codex Alimentarius, 2001a, b).

In the present study $\mathrm{Zn}$ concentration was found more in root $5677.7 \mathrm{ppm}$ compared to stem $2434.0 \mathrm{mg} \mathrm{kg}^{-1}$ and leaves $1666.8 \mathrm{mg} \mathrm{kg}^{-1}$ which is however higher than the permissible limits (FAO/WHO, Codex Alimentarius, 2001a, b).Zinc is an essential element to plants. Its mean concentration in the aboveground tissues of normal plants was $66 \mathrm{mg} \mathrm{kg}^{-1}$ (Outridge and Noller, 1991), while the toxic level being up to $230 \mathrm{mg}$ $\mathrm{kg}^{-1}$ (Borkert et al., 1998; Long et al., 2003).

The concentration of $\mathrm{Mn}$ in the present study was found more in stem $4552.3 \mathrm{mg}$ $\mathrm{kg}^{-1}$ followed by that of leaves $3003.4 \mathrm{mg} \mathrm{kg}^{-1}$ and root $2974.6 \mathrm{mg} \mathrm{kg}$. Higher concentration of $\mathrm{Mn}$ in leaves of Chinese chestnut and sugarcane plants indicated its high mobility or transfer ability (Li et al., 2007), as leaf chlorophyll content requires $\mathrm{Mn}$ 
for photosynthesis. In contrast, Gupta and Sinha (2007) reported higher accumulation of $\mathrm{Mn}$ in roots followed by leaves in Chenopodium. Normal concentrations of $\mathrm{Mn}$ fall within the wide range of $20-500 \mathrm{mg} \mathrm{g}^{-1}$ of plant dry matter, and occasionally exceed $1000 \mathrm{mg} \mathrm{g}^{-1}$ in plants grown on normal soils (Reeves and Baker, 2000). The Mn concentration in vegetables was reported to vary from 5.10 to $162.40 \mathrm{mg} \mathrm{kg}^{-1}$ (Adhikari et al., 1998; Murtaza et al., 2003). Furthermore, an operational definition was proposed by Baker (1981) that in accumulator plants the Mn contents in shoots is invariably higher than in roots, showing a special capability of the plants to accumulate and transport Mn and store in their above-ground parts (Reeves and Baker, 2000; Ebbs and Kochian, 1998).

The concentration of $\mathrm{Cd}$ in the present study was found to be higher in root $610.6 \mathrm{mg}$ $\mathrm{kg}^{-1}$ compared to stem $258.9 \mathrm{mg} \mathrm{kg}^{-1}$ and leaves $495.4 \mathrm{mg} \mathrm{kg}^{-1}$ which is also higher than the permissible limits (FAO/WHO, Codex Alimentarius, 2001a, b). Thus, B. juncea is a hyper accumulator of $\mathrm{Cd}$. $\mathrm{Cd}$ is known to accumulate more in roots, particularly when plants are grown on contaminated soil (Kabata-Pendias and Pendias, 1992). Traynor and Knezek (1973) reported that corn grown on Cd-enriched soils readily absorbed and translocated Cd to aboveground plant parts. Donghua et al., 2001 also indicated in garlic plant that the Cd ions were accumulated mainly in the roots, and only small amounts of $\mathrm{Cd}$ were translocated to the bulbs and the shoots.A Cd hyperaccumulator plant is defined as a plant species capable of accumulating more than $100 \mathrm{mg} \mathrm{kg}^{-1}$ (dry wt.) in the shoots (Baker et al., 2000).

Copper is also an essential element for plant growth, but causes toxic effects when shoots or leaves accumulate $\mathrm{Cu}$ levels exceeding $20 \mathrm{mg} \mathrm{kg}^{-1}$ (Borkert et al., 1998). An average $\mathrm{Cu}$ concentration of $37 \mathrm{mg} \mathrm{kg}^{-1}$ was recorded in the aboveground tissues of $T$. latifolia in uncontaminated sites (Outridge and Noller 1991). Cu concentrations in roots were geater than the shoots in $B$. juncea grown in $\mathrm{Cu}$ amended soil (Ariyakanon and Winaipanich, 2006). In present study, the accumulation of $\mathrm{Cu}$ was found higher in roots $1306.8 \mathrm{mg} \mathrm{kg}^{-1}$ than that of stem $764.3 \mathrm{mg} \mathrm{kg}^{-1}$ and leaves $754.8 \mathrm{mg} \mathrm{kg}^{-1}$ which is higher than the permissible limits (FAO/WHO, Codex Alimentarius, 2001a, b). The modest concentration of $\mathrm{Cu}$ found in roots could be due to its increased mobility from soil to roots indicating the affinity of roots to accumulate good amount of $\mathrm{Cu}$ and transferring a little to above ground plant parts. These findings are in conformation with that of Jarvis et al. (1976), (Leita et al., 1993; Yang et al., 2002). Xiong and Wang (2005) found that $\mathrm{Cu}$ concentration in the stem of vegetables was considerably influenced by its concentration in soil and increased noticeably with an increase in the soil.

The order of accumulation of the heavy metals in different parts of B. juncea was root $>$ stem $>$ leaf for $\mathrm{Pb}$, root $>$ stem $>$ leaf for $\mathrm{Zn}$, root $>$ stem $>$ leaf for $\mathrm{Cu}$ and root $>$ stem > leaf for $\mathrm{Cd}$; and it was stem > leaf > root for Mn across all the treatments. It indicated the affinity of roots to accumulate good amount of metals from soil and transfer a little amount to above ground plant parts. These results are in conformation with the findings of Jarvis et al. (1976) and Leita et al. (1993), who noticed accumulation of heavy metals was more in root system than the aerial parts.

The BAC indicates the bioaccumulation of heavy metals in roots from soil, and BTC indicates mobility of heavy metals from root to aerial plant parts. The coefficient factors are the main factors for selecting plants for removal of heavy metals. In the present study, the BAC and BTC values for $\mathrm{Pb}, \mathrm{Zn}, \mathrm{Cd}$ and $\mathrm{Cu}$ across the treatments are $>1$; indicating higher accumulation of the metals from soil to root as well as translocation 
from root to aboveground plant parts. The BTC is $>1$ for $\mathrm{Mn}$ in the plant, which shows higher accumulation of the metal in aerial parts, i.e. stem and leaves. Li et al. (2007) explained the BAC and BTC of the 12 dominant plants, and reported that BAC of Cd was $>1$, which implied the plants tended to have higher $\mathrm{Cd}$ accumulation in leaves, while for other metals like $\mathrm{Pb}, \mathrm{Cu}$ and $\mathrm{Mn}, \mathrm{BACs}$ were $<1$ except Castanea henryi and Phytolacca acinosa for Mn, while the BTC in most plants had a higher Mn transfer rate. In particular, four plants (P. acinosa, C. henryi, Osmanthus fordii and Parthenocissus heterophylla) showed very high Mn transfer ability with BTC being larger than 7.5. Both BAC and BTC are $>1$ for five plant species (Erigeron canadensis, P. acinosa, $O$. fordii, $C$. henryi and $P$. heterophylla) for $\mathrm{Cd}$, and two species $(C$. henryi and $P$. acinosa) for Mn. Gupta et al. (2008) demonstrated that Transfer Factor of heavy metals - $\mathrm{Mn}, \mathrm{Zn}, \mathrm{Cu}$ and $\mathrm{Cd}$ from soil showed average value of $<1$ in tomato plants, which suggested less uptake of heavy metals from soil.

Present findings revealed that Level 1 registered high mobility rate for $\mathrm{Pb}, \mathrm{Zn}, \mathrm{Cu}$ and Cd than Level 2 and Level 3 whereas Mn showed higher mobility rate in level 3 and level 2 (Table 4). The analysis also showed that the translocation of heavy metals in different levels (soil to root, root to stem and stem to leaves) hardly followed any specific pattern; it varied with the species of metal. Mn showed higher translocation values for leaves and stem, whereas $\mathrm{Cd}$ showed such values for leaves, while $\mathrm{Pb}, \mathrm{Zn}$ and $\mathrm{Cu}$ showed such values for root. Gupta et al. (2008) explained that translocation of the heavy metals from soil to root was in sequence of $\mathrm{Fe}(0.96)>\mathrm{Cd}(0.77)>\mathrm{Cu}(0.52)>$ $\mathrm{Zn}(0.37)>\mathrm{Mn}(0.28)>\mathrm{Cr}(0.25)$ which were $<1$. This implies that although distribution of metals is quite high in treated soil, their movement from soil to plant is restricted may be due to some physical factors like $\mathrm{pH}$ and CEC of soil and also because of some inherent resistive mechanism (phytochelation) within the plant body (Gupta et al., 2008).

\section{Conclusion}

The present study showed the heavy metal accumulation in different plant parts of B.juncea, a hyper accumulator grown on coastal loamy soil amended with municipal organic solid waste compost. The ranking order of metal accumulation in plant parts was root > stem > leaf for $\mathrm{Pb}, \mathrm{Zn}, \mathrm{Cu}$ and $\mathrm{Cd}$; and stem > leaf > root for $\mathrm{Mn}$ across the treatments. Further, it showed that the heavy metal accumulation by the plant parts is highly dependent on their concentration in respective treatments. The metal accumulation in root, stem and leaves of B. juncea was significantly different across different treatments and the native soil $(\mathrm{P}<0.05)$. The BAC and BTC indicated that $\mathrm{Pb}$, $\mathrm{Zn}, \mathrm{Cd}$ and $\mathrm{Cu}$ were accumulated more in root followed by stem and leaves while $\mathrm{Mn}$ accumulated more in stem followed by leaves and root. Translocation of $\mathrm{Pb}, \mathrm{Zn}, \mathrm{Cu}$ and $\mathrm{Cd}$ was more from soil to root whereas translocation of Mn was more from root to stem and stem to leaves. Mobility of the metals in plant parts does not show any specific pattern as it depends on metal species. Concentrations of heavy metals in different plant parts were found more than the permissible limits. Hence, $B$.juncea is a good accumulator and can be used in phytoremediation of heavy metals.

Acknowledgement. The University Grants Commission (New Delhi, India) provided funding for this research in the form of a major research project (F. No. 32-634/2006(SR), dated 02-03-2007). DS was awarded a research fellowship under the research project. 


\section{REFERENCES}

[1] Abe, T., Fukami, M., Ichizen, N., Ogasawara, M. (2006): Susceptibility of weed species to cadmium evaluated in a sand culture. - Weed Biolog. Manage 6(2): 107-114.

[2] Adhikari, S., Mitra, A., Gupta, S.K., Banerjee, S.K. (1998): Pollution metal contents of vegetables irrigated with sewage water. - J. Indian Soc. Soil Sci. 46(1): 153-155.

[3] Alkorta, I., Herna'ndez-Allica, J., Becerril, J.M., Amezaga, I., Albizu, I., Garbisu, C. (2004): Recent findings on the phytoremediation of soils contaminated with environmentally toxic heavy metals and metalloids such as zinc, cadmium, lead, and arsenic. - Reviews in Environ. Sc. Bio/Technol. 3: 71-90.

[4] Alloway, B.J. (1995): Heavy Metals in Soils. - In: Alloway, B.J. (ed.) Blackie Academic and Professional, 2nd edn., Glasgow, United Kingdom, pp. 363.

[5] Ariyakanon, N., Winaipanich, B. (2006): Phytoremediation of copper contaminated soil by Brassica juncea (L) CZern and Bidens alba (L) DC. Var. radiate. - J. Sci. Res. 31(1).

[6] Baker, A.J.M. (1981): Accumulators and excluders-strategies in the response of plants to heavy metals. - J. of Plant Nutrition. 3(1-4): 643-654.

[7] Baker, A.J.M., McGrath, S.P., Reeves, R.D., Smith, J.A.C. (2000): Metal hyperaccumulator plants: a review of the ecology and physiology of a biological resource for phytoremediation of metal-polluted soils. - In: Terry, N., Banuelos, G., Vangronsveld, J. (eds.) Phytoremediation of Contaminated Soil and Water, Lewis Publisher, Boca Raton, FL., 85-107.

[8] Barman, S.C., Sahu, R.K., Bhargava, S.K., Chatterjee, C. (2000): Distribution of heavy metals in wheat, mustard, and weed grown in fields irrigated with industrial effluents. Bull. Environ. Contam. Toxicol. 64: 489-496.

[9] Bernal, M.P., Clemente, R., Walker, D.J. (2005): Uptake of heavy metals and As by Brassica juncea grown in a contaminated soil in Aznalco' llar (Spain): The effect of soil amendments. - Environ. Pollut. 138: 46-58.

[10] Blaylock, M.J., Salt, D.E., Dushenkov, S., Zakharova, O., Gussman, C. , Kapulnik, Y., Ensley, B.D., Raskin, I. (1997): Enhanced accu-mulation of Pb in Indian Mustard by soilapplied chelating agents. - Environ. Sc. and Technol. 31(3): 860-865.

[11] Borkert, C.M., Cox, F.R., Tucker, M.R. (1998): Zinc and copper toxicity in peanut, soybean, rice and corn in soil mixtures. - Commun. in Soil Sc. and Plant Analysis 29: 2991-3005.

[12] Breckle, S.W. (1991): Growth under stress: Heavy metals. - In: Waisel, Y., Eshel, A., Kafkafi, U. (eds.) Plant Roots-The Hidden Half, Marcel Dekker, New York, 351-373.

[13] Bunzl, K., Trautmannsheimer, M., Schramel, P., Reifenhäuser, W. (2001): Availability of Arsenic, Copper, Lead, Thallium, and Zinc to Various Vegetables Grown in SlagContaminated Soils. - J. Environ. Qual. 30(3): 934-939.

[14] Cabrera, F., Duaz, E, Madrid, L. (1989): Effect to fusing urban compost as manre on soil contents of some nutrients and heavy metals. - J. Sci. Food Agric. 47: 159-169.

[15] Codex Alimentarius (2001a): Codex maximum levels for Cadmium in Cereals, Pulses and Legumes, Joint FAO/WHO Standards, CAC/GL 39-2001. http//www.codexalimentarius.net/standards_search.asp. (accessed March 2004).

[16] Codex Alimentarius (2001b): Maximum levels for Lead, Joint FAO/WHO Standards, Codex STAN 230-2001. - http//www.codexalimentarius.net/standards_search.asp (accessed March 2004).

[17] Codex Alimentarius Commission, Contaminants (1984): Joint FAO/WHO Food Standards Program. - Codex Alimenturius, XVII.

[18] De Jager, A., Onduru, D., Van Wijk, M.S., Vlaming, J., Gachini, G.N. (2001): Assessing sustainability of low external input farm management systems with the nutrient monitoring approach: a case study in Kenya. - Agric. Syst. 69: 99-118. 
[19] Ebbs, S.D., Kochian, L.V. (1998): Phytoextraction of zinc by oat (Avena sativa), barley (Hordeum vulgare) and Indian mustard (Brassica juncea). - Environ. Sc. and Technol. 32(6): 802-806.

[20] Epelde, L., Jose, M.B., Javier, H.A., Barrutia, O., Garbisu, C. (2008): Functional diversity as indicator of the recovery of soil health derived from Thlaspi caerulescens growth and metal phytoextraction. - Appl. Soil Ecol. 39: 299-310.

[21] Farooq, M., Anwar, F., Rashid, U. (2008): Appraisal of heavy metal contents in different vegetables grown in the vicinity of An industrial area. - Pak. J. Bot. 40(5): 2099-2106.

[22] Food Standard Committee (1950): Reports on Copper and Zinc. - Ministry of Agriculture, Fisheries and Food, UK.

[23] Gallardo-Lara, F., Nogales, R. (1987): Effect of the application of town refuse compost ont he soil plant system. A review. - Biol. Vastes. 19: 35-62.

[24] Garbisu, C., Alkorta, I. (2000): Phytoextraction: A cost-effective plant-based technology for the removal of metals from the environment. - Bioresour. Technol. 77(3): 229-236.

[25] Gosh, M., Singh, S.P. (2005): Comparative uptake and phytoextraction study of soil induced chromium by accumulator and high biomass weed species. - App. Ecol. Environ. Res. 3(2): 67-79.

[26] Gupta, A.K., Sinha, S. (2007): Phytoextraction capacity of the Chenopodium album L. grown on soil amended with Tannery sludge. - Bioresour. Technol. 98: 442-446.

[27] Gupta., Nayek, S.S., Saha, R.N., Satpati, S. (2008): Assessment of heavy metal accumulation in macrophyte, Agricultural soil, and plants adjacent to discharge zone of sponge iron factory. - Environ. Geol. 55: 731-739.

[28] He, X.T., Traina, S.J., Logan, T.J. (1992): Chemical properties of municipal solid waste composts. - J. Environ. Qual. 21: 318-329.

[29] Huang, J.W., Cunningham, S.D. (1996): Lead phytoextraction: Species variation in lead uptake and translocation. - New Phytologists 134: 75-84.

[30] Hughes, J.B., Shanks, J., Vanderford, M., Lauritzen, J., Bhadra, R. (1997): Transformation of TNT by aquatic plants and plant tissue cultures. - Environ. Sc. Technol. 31: 266-271.

[31] Intawongse, M., Dean, J.R. (2006): In-vitro testing for assessing oral bioaccessibility of trace metals in soil and Food samples. - Trends in Analyt. Chemistry 25(9): 876-886.

[32] Itanna, F. (2002): Metals in leafy vegetables grown in Addis Ababa and toxicological implications. - Ethiopian J. Health Develop. 6(3): 295-302.

[33] Jarvis, S.C., Jones, L.H.P., Hopper, M.J. (1976): Cadmium uptake from solution by plants and its transport from roots to stems. - Plant Soil. 44: 179-191.

[34] Kabata-Pendias, A., Pendias, H. (1992): Trace Elements in Soil and Plants. - $2^{\text {nd }}$ ed. CRC Press, Boca Raton, FL.

[35] Kirkham, M.B. (2006): Cadmium in plants on polluted soils: Effects of soil factors, hyperaccumulation and amendments. - Geoderma 137: 19-32.

[36] Kumar, P.B.A.N., Dushenkov, V., Motto, H., Raskin, I. (1995): Phytoextraction: The use of plants to remove heavy metals from soils. - Environ. Sc. Technol. 29(5): 1232-1238.

[37] Kumar, S., Bhattacharyya, J.K., Vaidya, A.N., Chakrabarti, T., Devotta, S., Akolkar, A.B. (2009): Assessment of the status of municipal solid waste management in metro cities, state capitals, class I cities, and class II towns in India: An insight. - Waste Manag. 29(2): 883-895.

[38] Lasat, M.M. (2002): Phytoextraction of toxic metals: A review of biological mechanisms. - J. Environ. Qual. 31(1): 109-120.

[39] Leita, L., De Nobili, M., Mondini, C., Balagarcia, M.T. (1993): Response of leguminosae to cadmium Exposure. - J. Plant Nutrients 16: 2001-2012.

[40] Li, M.S., Luo, Y.P., Su, Z.Y. (2007): Heavy metal concentrations in soils and plant accumulation in a restored manganese mine land in Guangxi, South China. - Environ. Pollut. 147(1): 168-175. 
[41] Li, T., Xiong, Z.T. (2004): A novel response of wild type duckweed (Lemna paucicostata Hegelm.) to heavy metals. - Environ. Toxicol. 19: 95-102.

[42] Liu, D., Jiang, W., Hou, W. (2001): Hyperaccumulation of cadmium by roots, bulbs and shoots of garlic (Allium sativum L.). - Bioresour. Technol. 76: 9-13.

[43] Long, X.X., Yang, X.E., Ni, W.Z., Ye, Z.Q., He, Z.L., Calvert, D.V., Sftoffella, J.P. (2003): Assessing zinc thresholds for phytotoxicity and potential dietary toxicity in selected vegetable crops. - Commun. in Soil Sc. Plant Analy. 34: 1421-1434.

[44] Madyiwa, S., Chimbari, M., Nyamangara, I., Bangira, C. (2002A): Cumulative effects of sewage sludge and effluent mixture application on soil properties of a sandy soil under a mixture of star and kikuyu grasses in Zimbabwe. - Phys. Chem. Earth Parts NB/C 27. 747-753.

[45] Madyiwa, S., Chimbari, M., Nyamangara, I., Bangira, C. (2002B): Phytoextraction capacity of Coynodon lemfuensis (star grass) at artificially elevated concentrations of $\mathrm{Pb}$ and $\mathrm{Cd}$ in sandy soils under greenhouse conditions. - In: Third WaterNet/Warfsa Symposium 'Water Demand Management for Suitable Development', Dar-es-Salaam. pp. $1-10$.

[46] Marchiol, L., Assolari, S., Sacco, P., Zerbi, G. (2004): Phytoextraction of heavy metals by canola (Brassica napus) and radish (Raphanus sativus) grown on multicontaminated soil. - Environ. Pollut. 132: 21-27.

[47] McGrath, S.P., Zhao, F.J., Lombi, E. (2002). Phytoremediation of metals, metalloids, and radionuclides. - Advances in Agronomy 75: 1-56.

[48] Meagher, R.B. (2000): Phytoremediation of toxic elemental and organic pollutants. Current Opinion in Plant Biol. 3: 153-162.

[49] Mishra, V.K., Upadhyaya, A.R., Pandey, S.K., Tripathi, B.D. (2008): Heavy metal pollution induced due to coal mining effluent on surrounding aquatic ecosystem and its management through naturally occurring aquatic macrophytes. - Bioresour. Technol. 99(5): 930-936.

[50] Murtaza, G., Ghafoor, A., Qadir, M., Rashid, M.K. (2003): Accumulation and bioavallability of $\mathrm{Cd}$, $\mathrm{Co}$ and $\mathrm{Mn}$ in soils and vegetables irrigated with city effluent. Pak. J. Agri. Sci. 40(1-2): 18-24.

[51] Nirmal, J.I.K., Soni, H., Rita, N.K., Bhatt, I. (2009): Technical Paper: Hyperaccumulation and mobility of heavy metals in vegetable crops In India. - The J. Agric. Environ. 10: 2938.

[52] Othman, O.C. (2001): Heavy metals in green vegetables and soils from vegetable gardens in Dar Es Salaam, Tanzania. - Tanzanian J. Sc. 27: 37-48.

[53] Oueedraogo, E., Mando, A., Zombree, N.P. (2001): Use of compost to improve soil properties and crop productivity under low input agricultural system in West Africa. Agric. Ecosyst. Environ. (84): 259-266.

[54] Outridge, P.M., Noller, B.N. (1991): Accumulation of toxic trace elements by freshwater vascular plants. - Reviews Environ. Contamin. Toxicol. 121: 1-63.

[55] Petruzzelli, G. (1996): Heavy metals in compost and their effect on soil quality. - In: De Bertoldi, M., Sequi, P., Lemmes, B., Papi, T. (eds.) The composting science, Part I., Blackie Academic and Professional Editor, Glasgow, pp: 212-223.

[56] Pichtel, J., Salt, C.A. (1998): Vegetative growth and trace metal accu-mulation on metalliferous wastes. - J. Environ. Qual. 27: 618-624.

[57] Pilon-Smits, E.A.H. (2005): Phytoremediation. - Annual Review of Plant Biology 56(1): 15-39.

[58] Prasad, M.N.V., Freitas, H. (2003): Metal hyperaccumulation in plants - Biodiversity prospecting for phytoremediation technology. - Electronic J. Biotechnol. 6(3): 275-321.

[59] Rai, P.K. (2008): Heavy metal pollution in Aquatic Ecosystems and its phytoremediation using wetland plants: An ecosustainable approach. - Int. J. Phytoremed. 10(2): 133-160. 
[60] Raskin, I., Smith, R.D., Salt, D.E. (1997): Phytoremediation of metals: using plants to remove pollutants from the environment. - Curr. Opinion in Biotechnol. 8: 221-226.

[61] Reddy, M.V., Pattnaik, S. (2009): Vermicomposting of Municipal (Organic) Solid Waste and its implications Chapter 10). - In: Singh, S.M. (ed.) 'Earthworm Ecology and Environment, International Book Distributing Co., Lucknow, India. pp. 119-133.

[62] Reeves, R.D., Baker, A.J.M. (2000): Metal-accumulating plants. - In: Raskin, I., Ensley, B.D. (eds.) Phytoremediation of Toxic Metals: Using Plants to Clean up the Environment, John Wiley \& Sons, Inc., New York. pp. 193-229.

[63] Scott, D., Keoghan, J.M., Alian, R.E. (1996): Native and low-input grassesa New Zealand high country perspective. - N. Z. J. Agric. Res. 39: 499-512.

[64] Shahmansouri, M.R., Pourmoghadas, H., Parvaresh, A.R., Alidadi, H. (2005): Heavy metals bioaccumulation by Iranian and Australian earthworms (Eisenia fetida) in the sewage sludge vermicomposting, Iranian and Australian earthworms (Eisenia fetida) in the sewage sludge vermicomposting. - Iranian J. Environ. Health 2(1): 28-32.

[65] Shyama, R. Weerakoon, Somaratne, S. (2009): Phytoextractive potential among mustard (Brassica juncea) genotypes in Srilanka. - Cey. J. Sci. (Bio Sci). 38(2): 85-93.

[66] Stamatiadis, S., Werner, M., Buchanan, M. (1999): Field assessment of soil quality as affected by compost and fertilizer application in a broccoli field (San Benito County, California). - App. Soil Ecol. 12: 217-225.

[67] Traynor, M.F., Knezek, B.D. (1973): Effects of nickel and cadmium contaminated soils on nutrient composition of corn plants. - In: Hemphill, DD. (ed.) Trace Substances in Environmental Health, VII. University of Missouri Annual Conference, pp. 82-87.

[68] Voutsa, D., Grimanis, A., Samara, C. (1996): Trace elements in vegetables grown in an industrial area in relation to soil and air particulate matter. - Environ. Pollut. 94(3): 325335.

[69] Xiong, Z.T., Wang, H. (2005): Copper toxicity and bioaccumulation in Chinese cabbage (Brassica pekinensis Rupr.). - Environ. Toxicol. 20(2): 188-194.

[70] Yang, X.E., Long, X.X., Ni, W.Z. (2002): Assessing copper thresholds for phytotoxicity and potential dietary toxicity in selected vegetables crops. - J. Environ. Sci. Health.Vol. B 37(6): 625-635.

[71] Yusuf, A.A., Arowolo, T.O.A., Bamgbose, O. (2002): Cadmium, copper and nickel levels in vegetables from industrial and residential areas of Lagos City, Nigeria. - Global J. Environ. Sc. 1(1): 1-6. 